\title{
Hepatit C Virüsü Enfeksiyonu Olan Hastalarda Viremi Tespitinde Anti-HCV S/CO Değerinin Araştırılması
}

\section{Investigation of Anti-HCV S/CO Value in Detecting Viremia in Patients with Hepatitis C Virus Infection}

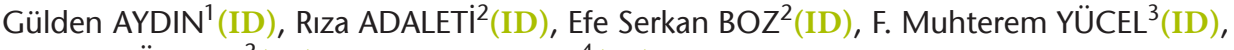

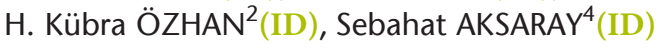 \\ 1 T.C. Sağlık Bakanlığı, Yozgat Şehir Hastanesi, Yozgat. \\ ${ }^{1}$ Republic of Turkey Ministry of Health, Yozgat City Hospital, Yozgat, Turkey. \\ ${ }^{2}$ Sağlık Bilimleri Üniversitesi, Haydarpaşa Numune Sağlık Uygulama ve Araştırma Merkezi, İstanbul. \\ ${ }^{2}$ Health Sciences University, Haydarpasa Numune Health Research Center, Istanbul, Turkey. \\ ${ }^{3}$ Sağlık Bilimleri Üniversitesi, Ümraniye Sağlık Uygulama ve Araştırma Merkezi, İstanbul. \\ ${ }^{3}$ Health Sciences University, Umraniye Health Research Center, Istanbul, Turkey. \\ ${ }^{4}$ Sağlık Bilimleri Üniversitesi, Hamidiye Tıp Fakültesi, Tıbbi Mikrobiyoloji Anabilim Dalı, İstanbul. \\ ${ }^{4}$ Health Sciences University, Hamidiye Faculty of Medicine, Department of Medical Microbiology, Istanbul, Turkey.
}

Makale Atıfı: Aydın G, Adaleti R, Boz ES, Yücel FM, Özhan HK, Aksaray S. Hepatit C virüsü enfeksiyonu olan hastalarda viremi tespitinde anti-HCV S/CO değerinin araştırılması. Mikrobiyol Bul 2020;54(1):110-119.

\section{ÖZ}

Hepatit C virüsü (HCV) enfeksiyonlarının laboratuvar tanısında anti-HCV ve HCV RNA testleri kullanılmaktadır. Özellikle HCV prevalansı düşük olan toplumlarda tarama amaçlı kullanılan anti-HCV testlerinde, yalancı pozitif sonuçlar sıklıkla gözlenmektedir. Doğrulama testi olan HCV RNA testi ise maliyeti yüksek ve ileri düzeyde teknik gerektiren bir test olması sebebiyle her laboratuvarda çalışılamamakta, bu durum hastaların tanı ve tedavisinin gecikmesine yol açabilmektedir. Bu çalışmada, retrospektif veriler kullanılarak, anti-HCV, alanin aminotransferaz (ALT) ve HCV RNA arasındaki ilişkinin analizi ile, laboratuvarımız için hastalardaki gerçek antikor pozitifliğini ve viremiyi göstermede optimal bir anti-HCV S/CO değerinin elde edilmesi amaçlanmıştır. Temmuz 2014-Temmuz 2017 tarihleri arasında 754.190 anti-HCV testi çaıışılmışıı. Anti-HCV sonucu reaktif olan 18 yaş ve üzeri hastalardan, eş zamanlı HCV RNA ve ALT istemi olan hastalar çalışmaya dahil edilmiştir. Anti-HCV tespiti için ikinci kuşak CMIA (Abbott, ABD) yöntemi kullanılmıştır. Kantitatif HCV RNA analizi için viral nükleik asit ekstraksiyonu QIAsymphony DSP virus/pathogen midi kit kullanılarak QIAsymphony SP/AS (Qiagen, Almanya) cihazı ile; polimeraz zincir reaksiyonu (PCR) ise Artus HCV QS-RGQ kiti kullanılarak Rotor-Gene Q (Qiagen, Almanya) cihazı ile yapılmıștır. ALT ölçümünde ARCHITECT c ve AEROSET sistemleri (Abbott, ABD) kullanılmıştır. HCV genotip tayini $(n=622$ olgu), çalışmamızın kapsadığı farklı dönemlerde 'GenoSen's HCV Genotyping 1/2/3/4 RG' kalitatif gerçek zamanlı PCR kiti (Corbett Research, Avustralya) ve 'GEN-C 2.0 reverse hybridization strip assay' (NLM Diagnostics, İtalya) kiti kullanılarak yapılmıştır. Anti-HCV, ALT ve HCV RNA arasındaki ilişki için en uygun eşik değer ROC analizine dayalı seçilmiştir. İstatistiksel anlamlılık $p<0.05$ olarak kabul edilmiştir. Çalışılan anti- 
HCV test sonuçlarından 10.679 'u reaktif bulunmuştur. Anti-HCV sonucu reaktif bulunan ve aynı serumda eş zamanlı HCV RNA ve ALT testi çalışılmış olan 1290 olgunun 1754 verisi değerlendirilmiştir. Bunların 742 (\%42)'sinde HCV RNA pozitif, 1012 (\%58)'sinde HCV RNA negatif bulunmuştur. HCV RNA sonucu pozitif olanların ALT ve anti-HCV düzeyleri, HCV RNA sonucu negatif olanlardan istatistiksel olarak anlamlı düzeyde yüksek bulunmuştur ( $p=0.001$ ). HCV RNA'ya göre anti-HCV S/CO için tespit edilen eşik değer 7.13 (duyarlılık \%97.4, özgüllük \%50.3, pozitif prediktif değer \%58.9, negatif prediktif değer \%96.4), ALT için tespit edilen eşik değer ise 27.5 IU/L (duyarlılık \%77.6, özgüllük \%80.8) bulunmuştur. HCV RNA pozitifliğinde anti-HCV ve ALT için ROC eğrisi altında kalan alan $0.5^{\prime}$ ten anlamlı şekilde yüksek bulunmuştur $(p=0.001)$. HCV genotipleri arasında ALT ve anti-HCV düzeyleri açısından istatistiksel olarak anlamlı bir farklıık bulunmamıştır. Yeni eşik değerimizin laboratuvar iş akışı içerisinde kullanılmasıyla birlikte, özellikle tarama amaçı anti-HCV çalışılmış olan bazı hastalardaki HCV RNA ile doğrulama ihtiyacı azaltılabilir. Anti-HCV değeri S/CO 7.13'ün altındaki reaktifliklerde, bu eşik değerin yüksek negatif prediktif değeri göz önüne alınarak tarama amaçı başvuran bir hastada yalancı pozitif bir sonuç HCV RNA sonucu beklenmeden öngörülebilir. Pozitif prediktif değerinin düşük olması nedeniyle 7.13 eşik değerinin üzerinde saptanan anti-HCV reaktifliklerinde hastada viremi olmaması ihtimali de göz önünde bulundurulmalıdır.

Anahtar kelimeler: Hepatit C; anti-HCV antikorlar; alanin aminotransferaz.

\section{ABSTRACT}

Anti-HCV and HCV RNA tests are used in laboratory diagnosis of hepatitis C virus (HCV) infections. False positive results are frequently observed in anti-HCV tests used as screening tests in societies with low prevalence of HCV. The HCV RNA test, which is a confirmatory test, is not performed in every laboratory because it is a high-cost and high-tech test, which can lead to delay in the diagnosis and treatment of patients. In this study, it was aimed to obtain an optimal anti-HCV S/CO value in our laboratory for demonstrating true antibody positivity and viremia in patients by analyzing the relationship between anti-HCV, alanine aminotransferase (ALT) and HCV RNA using retrospective data. Between July 2014 and July 2017, 754.190 anti-HCV tests were performed. Patients aged 18 years or older who were reactive with anti-HCV and those with simultaneous HCV RNA and ALT prompts were included in the study. The second generation CMIA (Abbott, USA) method was used for anti-HCV detection. For quantitative HCV RNA analysis, viral nucleic acid extraction was performed with the QIAsymphony SP/AS (Qiagen, Germany) using the QIAsymphony DSP Virus/Pathogen Midi Kit; and PCR was performed by Rotor-Gene Q (Qiagen, Germany) using Artus HCV QS-RGQ kit. ARCHITECT c and AEROSET systems (Abbott, USA) were used for ALT measurement. HCV genotype determination (622 cases) was performed using GenoSen's HCV Genotyping 1/2/3/4 RG qualitative real time PCR kit (Corbett Research, Australia) and GEN-C 2.0 Reverse Hybridization Strip Assay (NLM Diagnostics, Italy) kit at different periods covered by our study. The optimal threshold value for the relationship between anti-HCV, ALT and HCV RNA was selected based on ROC analysis. Statistical significance was accepted as $p<0.05$. Of the anti-HCV test results, 10.679 were found to be reactive. 1754 data of 1290 cases with anti-HCV reactivity who were simultaneously tested for HCV RNA and ALT in the same serum were evaluated. Of these, 742 (42\%) were found to be HCV RNA positive and 1012 (58\%) were found to be HCV RNA negative. ALT and anti-HCV levels of those who were positive for HCV RNA were significantly higher than those with negative HCV RNA $(p=0.001)$. The threshold point for anti-HCV S/CO according to HCV RNA was found to be 7.13 (sensitivity of $97.4 \%$, specificity of $50.3 \%$, positive predictive value $58.9 \%$, negative predictive value $96.4 \%$ ), and the cut-off point for ALT was found to be $27.5 \mathrm{IU} / \mathrm{L}$ (sensitivity of $77.6 \%$, specificity of $80.8 \%$ ). For HCV RNA positivity, the area under the ROC curve for anti-HCV and ALT was significantly higher than $0.5(p=0.001)$. No statistically significant difference was found between HCV genotypes in terms of ALT and anti-HCV levels. By using our new threshold in the laboratory workflow, the need to verify with HCV RNA can be reduced, especially in some patients who have been screened for anti$\mathrm{HCV}$ for screening purposes. Anti-HCV values below $7.13 \mathrm{~S} / \mathrm{CO}$, considering the high negative predictive value of this threshold; a false positive result in a patient presenting for screening can be predicted without waiting for the HCV RNA result. In anti-HCV reactivities determined above 7.13, the possibility of absence of viremia should be considered due to the low positive predictive value.

Keywords: Hepatitis C; anti-HCV antibodies; alanine aminotransferase. 


\section{Giriş}

Hepatit C virüsü (HCV), non-A non-B hepatit etkeni olarak ilk defa Choo ve arkadaşları tarafından 1989 yılında tanımlanmıştır ${ }^{1}$. Virüs partikülünün yapısı, genom organizasyonu ve replikasyon döngüsünün özellikleri nedeniyle Flaviviridae ailesinin Hepacivirus cinsinde sınıflandıılan HCV, yaklaşık $50 \mathrm{~nm}$ çapında küresel yapıda zarflı bir ribonükleik asit (RNA) virüsüdür ${ }^{2,3}$. Tedavisiz olgular başta olmak üzere HCV ile enfekte bireylerin önemli bir kısmının kronik karaciğer hastalığı ve hepatoselüler karsinom için aday olması, HCV'yi önemli bir halk sağlığı sorunu haline getirmektedir. Dünya Sağlık Örgütünün 2017 Küresel Hepatit Raporu verileri, dünyada kronik HCV enfeksiyonu olan 71 milyondan fazla kişi bulunduğunu ve HCV'ye bağlı ölümlerin yıllık 399.000 civarında olduğunu göstermektedir. Dünya genelinde 2015 yılı içinde 1.75 milyon yeni HCV enfeksiyonu geliştiği tahmin edilmektedir. Bu rakam, tüm dünyada yılda yaklaşık 100.000'de 24 yeni HCV enfeksiyonu meydana geldiğini göstermektedir ${ }^{4}$. T.C. Sağlık Bakanlığı tarafından 2018 yılında yayımlanan Türkiye Viral Hepatit Önleme ve Kontrol Programında, 18 yaş üstü nüfusta yaklaşık 250.000-550.000 kişinin HCV ile enfekte olduğu ve HCV ile enfekte olanların büyük çoğunluğunun bu durumun farkında olmadığı bildirilmiştir. Sağlık Bakanlığının 2016 verilerine göre ülkemizde karaciğer transplantasyonunun ikinci en sık nedeni HCV olmakla birlikte, anti-HCV pozitifliğinin hemodiyaliz hastalarında \%3.8, periton diyalizi yapılan hastalarda \%1.7, böbrek transplantasyonu yapılan hastalarda \%1.96, karaciğer transplantasyonu yapılan hastalarda ise $\% 7.6$ olduğu bildirilmiştir 5 .

Hastalığın doğal seyrinin uzun olması dışında ilerleyişinin tüm ayrıntıları bilinmemektedir. Akut viral HCV enfeksiyonu sıklıkla asemptomatik seyretmekte, tedavisiz bırakılan tüm akut olgular kronik viral hepatit C'ye ilerlemektedir. Kronik HCV enfeksiyonu olan hastaların \%20 ile \%30'unda ortalama 25 yıl içerisinde karaciğer sirozu gelişmektedir. Siroz gelişen hastalarda hepatoselüler karsinom gelişme riski \%0-3 arasında değişmektedir.

HCV enfeksiyonu tanııında virüsün bulaşını takip eden ilk haftalarda moleküler yöntemler kullanılarak kişinin serum veya plazma örneğinde HCV RNA saptanabilmektedir. Anti-HCV antikorları ise üçüncü nesil "enzyme immun assay (EIA)" yöntemlerinin kullanımı ile HCV bulaşının sekizinci haftasından itibaren kişinin serumunda saptanabilmektedir. Serum aminotransferazları, 1-26. haftalar arasında yükselmeye başlamakta ve HCV enfeksiyonu süresince aminotransferaz düzeylerinde dalgalanmalar gözlenmektedir ${ }^{6}$. Geçmişte EIA yöntemleri ile alınan reaktif sonuçların doğrulanması amacıyla "recombinant immunoblot assay (RIBA)" testleri kullanılmıştır. Özellikle belirsiz sonuçların sık görülmesi nedeniyle daha önceleri doğrulama testi olarak kullanılan RIBA testi, 2013 yllında Amerikan Hastalık Kontrol ve Önleme Merkezi (Centers for Disease Control and Prevention, CDC) tarafından HCV tanı algoritmasından çıkarıımışıı ${ }^{7}$. Yeni HCV tanı algoritmasında, ilk olarak anti-HCV tarama testi ile HCV antikorlarının araştırılması, reaktif saptanan örneklerde HCV RNA testi çalışııması önerilmektedir. Bu aşamadan sonra anti-HCV sonucu reaktif olan bir örnekte, HCV RNA testi negatif ise ek bir anti-HCV antikor testinin daha yapılması veya hasta ile ilgili klinik şüphenin güçlü olması durumunda HCV RNA testinin tekrarlanması önerilmektedir. Aynı zamanda CDC, anti-HCV S/CO değerlerinin toplum 
özelliklerine bakılmaksızın sistem verilerinin analizi ile elde edilebileceğini bildirmekte ve laboratuvarların kendi HCV tanı algoritmalarını oluşturabileceğini önermektedir ${ }^{8}$.

Bu çalışmada, anti-HCV kaynaklı yalancı pozitif sonuçları en aza indirmek, yalancı pozitif anti-HCV sonuçları nedeniyle gereksiz HCV RNA çalışılmasını azaltmak ve HCV RNA testinin çalışılamadığı sağlık birimlerindeki meslektaşlarımıza hastalardaki HCV viremisini öngörmede yol gösterici olacak bir anti-HCV cut-off değerinin belirlenmesi ile birlikte, bu eşik değer kullanılarak kendi laboratuvarımız için yeni bir HCV tanı algoritmasının oluşturulması amaçlanmıştır.

\section{GEREÇ ve YÖNTEM}

Bu çalışma, T.C. Sağlık Bakanlığı Haydarpaşa Eğitim ve Araştırma Hastanesi Klinik Araştırmalar Etik Kurulu onayı ile gerçekleştirildi (Tarih: 09.10.2017 ve Karar no: HNEAH-KAEK2017/KK/120).

\section{Hasta Grubu}

Bu çalışma, 1 Temmuz 2014-1 Temmuz 2017 tarihleri arasında çalışılmış olan antiHCV, HCV RNA ve alanin aminotransferaz (ALT) değerlerinin karşılaştırıldığı metodolojik bir araştırmadır. Çalışmaya dahil edilme kriterleri 18 yaş üzerinde olan, anti-HCV sonucu reaktif olan ve anti-HCV ile eş zamanlı HCV RNA ve ALT istemi olan hastalar; hariç tutma kriterleri ise 18 yaş altı olan ve anti-HCV sonucu reaktif olmayan kişiler ve anti-HCV reaktif fakat eş zamanlı ALT ve HCV RNA çalışılmayan hastalar olarak belirlendi.

Çalışmamızda üç yıllık dönemde 754.190 anti-HCV testi çalışıldı. Bu analizlerden 10.679 test sonucu reaktif bulundu. Anti-HCV test sonucu reaktif olan 10.679 sonuç içinden anti-HCV ile eş zamanlı HCV RNA ve ALT istemi olan 1290 olgunun 1766 verisine ulaşıldı. Yaş bilgisi yanlış olması nedeniyle, 1766 hasta verisinden 12 hastanın çalışmadan çıkarılarak 1754 hasta verisi ile çalışmaya devam edildi. Bu hastaların verisi içerisinde 464 veri aynı hastanın farklı zamanlarda çalışılan test sonuçlarını içermesine rağmen, veri zenginliği sağlaması açısından çalışmadan çıkarılmadı. Demografik verilerin dağılımı ise 1290 hasta üzerinden incelendi.

\section{Anti-HCV Sonuçlarının Belirlenmesi}

Anti-HCV tespiti için ikinci nesil kemilüminesans mikropartikül immün yöntem (chemiluminescence microparticule immunoassay) (CMIA) ile çalışan ARCHITECT Anti-HCV kiti (Abbott, ABD) kullanıldı.

\section{Kantitatif HCV RNA Analizi}

Viral nükleik asit izolasyonu "QIAsymphony DSP virus/pathogen midi kit" (Qiagen, Almanya) ve "QIAsymphony SP/AS" (Qiagen, Almanya) cihazı ile, polimeraz zincir reaksiyonu (PCR) ise "Artus HCV QS-RGQ" (Qiagen, Almanya) kiti ve "Rotor-Gene Q" (Qiagen, Almanya) cihazı kullanılarak yapıldı. 


\section{HCV Genotip Analizi}

Çalışmamızı kapsayan farklı dönemlerde "GenoSen's HCV Genotyping 1/2/3/4 RG" kalitatif gerçek zamanlı PCR kiti (Corbett Research, Avustralya) ve "GEN-C 2.0 reverse hybridization strip assay" (NLM Diagnostics, İtalya) kitleri kullanılarak yapıldı. ALT ölçümü ARCHITECT c ve AEROSET sistemi (Abbott, $A B D$ ) ile yapıldı.

\section{İstatistiksel Analiz}

IBM SPSS Statistics 22 (IBM SPSS, Türkiye) programı kullanıldı. Çalışma verileri değerlendirilirken parametrelerin normal dağılıma uygunluğu Shapiro Wilks testi ile değerlendirildi ve parametrelerin normal dağılım göstermediği saptandı. Tanımlayıcı istatistiksel yöntemlerin (ortalama, standart sapma, frekans) yanı sıra niceliksel verilerin karşılaştırılmasında Mann-Whitney U test kullanıldı. En uygun eşik noktası "received operatör characteristic (ROC)" yani alıc işletim karakteristiği eğrisi analizine dayalı seçildi. Elde edilen eşik değer için duyarlılık, özgüllük, pozitif prediktif değer ve negatif prediktif değer hesaplamaları yapıldı. Anti-HCV ve ALT parametreleri için ROC eğrisinden belirlenen yeni eşik değerlere göre pozitif ve negatif kuralları SPSS programında yeniden düzenlenerek elde edilen eşik değer ile HCV RNA pozitiflik tanısı arasındaki ilişki ki-kare testi ile belirlendi. Anlamlılık p< 0.05 düzeyinde değerlendirildi.

\section{BULGULAR}

Yaş ortalaması 53.8 (SD \pm 15.5$)$ yıl olan olgularımızın 546 (\%42)'sı erkek, 744 (\%58)'ü kadın hastalardan oluşmuştur $(n=1290)$.

Verilerin çoğunu gastroenteroloji ve enfeksiyon hastalıkları kliniklerinde yatmakta olan hastalar oluşturmuştur. Olguların sistemdeki tanıları incelendiğinde 944'ünün kronik hepatit C, 34'ünün hepatit B, dokuzunun akut viral hepatit, 152'sinin karaciğer hastalıkları ile ilgili tanıya sahip ve 151 olgunun ise viral hepatit ve karaciğer hastalığı dışında bir tanısının olduğu gözlenmiştir.

Anti-HCV ve ALT test sonuçlarının dağılımı incelendiğinde parametrelerin normal dağılım göstermediği saptanmıştır. Anti-HCV için medyan değer 11.9 [interquartile range $(I Q R)=8.81]$, ALT için medyan değer $24(I Q R=30.3)$ olarak bulunmuştur (Tablo I).

Sonuçların 742 (\%42)'sinde HCV RNA pozitif, 1012 (\%58)'sinde HCV RNA negatif bulunmuştur. HCV RNA sonucu pozitif olanların ALT ve anti-HCV düzeyleri, HCV RNA sonucu negatif olanlardan istatistiksel olarak anlamlı düzeyde yüksek bulunmuştur $(p=$ 0.001) (Tablo II).

\begin{tabular}{lccccc} 
Tablo I. ALT ve Anti-HCV Deskriptif Analiz Değerleri \\
\hline & Minumum & Maksimum & Medyan & $\begin{array}{c}\text { Interquartile } \\
\text { range (IQR) }\end{array}$ & Range \\
\hline Anti-HCV (S/CO) & 1.01 & 78.86 & 11.9 & 8.81 & 77.85 \\
ALT (IU/L) & 6 & 1055 & 24 & 30.3 & 1049 \\
\hline
\end{tabular}

ALT: Alanin aminotransferaz, HCV: Hepatit C virüsü. 


\begin{tabular}{lcc}
\hline \multicolumn{3}{l}{ Tablo II. ALT ve Anti-HCV Değerlerinin HCV RNA Sonucuna Göre Değerlendirilmesi } \\
\hline HCV RNA & ALT (IU/L) (medyan) & Anti-HCV (S/CO) (medyan) \\
\hline Negatif & 17 & 7.07 \\
Pozitif & 45 & 13.13 \\
$\mathrm{p}$ & $0.0001^{*}$ & $0.0001^{*}$ \\
\hline * Mann-Whitney U Test $\mathrm{p}<0.05$. & & \\
ALT: Alanin aminotransferaz, HCV: Hepatit C virüsü. &
\end{tabular}

HCV RNA pozitifliğinde anti-HCV ve ALT için ROC eğrisi çizilmiştir. Anti-HCV için eğri altında kalan alan 0.761 ( $\mathrm{SE}=0.01)$, ALT için eğri altında kalan alan $0.856(\mathrm{SE}=0.01)$ bulunmuştur. Her iki parametre için ROC eğrisi altında kalan alan $0.5^{\prime}$ ten anlamlı şekilde yüksek bulunmuştur ( $p=0.001$ ) (Şekil 1).

ROC analizi ile duyarlılık ve özgüllük dengesi en iyi olan anti-HCV S/CO için 7.13 (duyarlılık > \%95), ALT için 27.5 IU/L noktaları yeni eşik değerleri olarak seçilmiştir (Tablo III).

Çalışmamızda 622 olguda HCV genotip analizi yapılmıştır. Olguların 522 (\%84)'sinde en sık genotip 1 saptanmış olup, subtiplerden 235 (\%37.7) olgu ile en sık subtip 1b tespit edilmiştir. Genotip 5, 6 ve 7 saptanmamıştır. Genotip 2 ve genotip 4 saptanan 15 olguda subtip ayrımı yapılamamış, altı örnekte genotip değişimi (veya karışık genotip) saptanmıştır. Genotip sonucu 1b olanlar ile diğer genotiplerin ALT ve anti-HCV ortalamaları arasında istatistiksel olarak anlamlı bir farklılık bulunmamıştır (sırasıyla $p=0.148$ ve $p=0.395$ ) (Tablo IV).

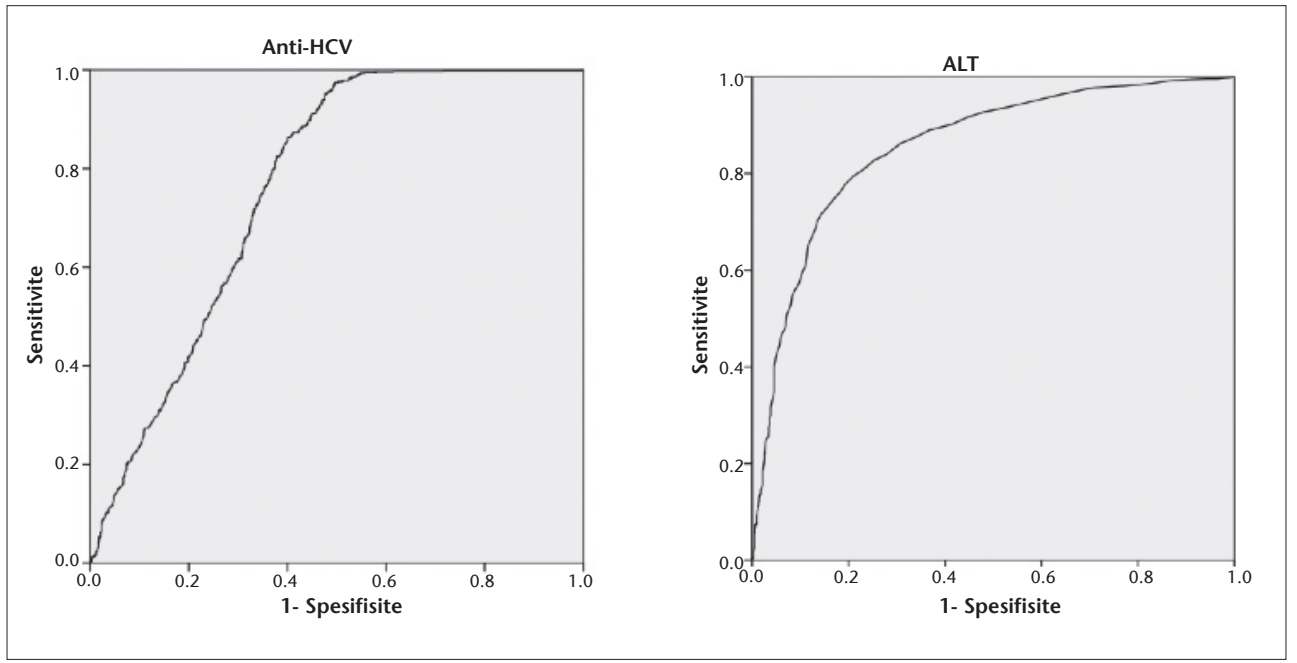

Şekil 1. Anti-HCV ve ALT için ROC eğrileri. 


\begin{tabular}{|c|c|c|c|c|c|c|}
\hline & Değer & $\begin{array}{c}\text { Duyarlılık } \\
(\%)\end{array}$ & $\begin{array}{l}\text { Özgüllü̈k } \\
(\%)\end{array}$ & $\begin{array}{c}\text { Pozitif } \\
\text { prediktif değer } \\
(\%)\end{array}$ & $\begin{array}{c}\text { Negatif } \\
\text { prediktif } \\
\text { değer (\%) }\end{array}$ & $\begin{array}{l}\text { Tanısal } \\
\text { Odds } \\
\text { oranı }\end{array}$ \\
\hline Anti-HCV (S/CO) & 7.13 & 97.4 & 50.3 & 58.9 & 96.4 & 38.4 \\
\hline ALT (IU/L) & 27.5 & 77.6 & 80.8 & 74.8 & 83.1 & 14.6 \\
\hline $\begin{array}{l}\text { Anti-HCV }(S / C O) \\
\text { ve ALT (IU/L) }\end{array}$ & $\begin{array}{l}7.13 \\
27.5\end{array}$ & 76 & 91.4 & 86.6 & 83.9 & 33.7 \\
\hline
\end{tabular}

\begin{tabular}{|lcc|}
\hline \multicolumn{3}{|l|}{ Tablo IV. ALT ve Anti-HCV Değerlerinin Genotip Sonucuna Göre Değerlendirilmesi } \\
\hline Genotip & ALT (IU/L) (medyan) & Anti-HCV (S/CO) (medyan) \\
\hline 1b & 37 & 13.18 \\
Diğer & 41 & 13.11 \\
p & $0.148^{*}$ & $0.395^{*}$ \\
\hline * Mann-Whitney U Test p< 0.05. & & \\
ALT: Alanin aminotransferaz, HCV: Hepatit C virüsü. & \\
\hline
\end{tabular}

\section{TARTIŞMA}

HCV'nin başlıca bulaş yolunun kan ve kan ürünleri olduğunun saptanmasından sonra, yeni olgu sayısını azaltmak amacıyla yapılan çalışmalar ile HCV'ye özgü antikorları saptayan EIA testlerinin ve sonrasında doğrulama testlerinin geliştirilmiş olması, 1990'lı yılların sonunda transfüzyonla ilişkili HCV enfeksiyon insidansının \%0.01'den daha aza düşmesine neden olmuştur ${ }^{9}$. Günümüzde gelişen HCV tarama yöntemleri ile birlikte bu rakamın bir milyon ünite transfüzyonda bire kadar düştüğü gösterilmiştir ${ }^{10}$. Bu tarama testleri HCV riskini azaltmada son derece etkili olmasına karşın, özellikle HCV prevalansı düşük olan toplumlarda, HCV enfeksiyonuna ait klinik bulguları olmayan bazı kişilerde yalancı pozitif test sonuçlarıyla sıklıkla karşılaşılmasına sebep olmaktadır ${ }^{11,12}$. CDC, özellikle HCV prevalansı düşük toplumlardaki yalancı pozitif anti-HCV test sonuçlarını azaltmak amacıyla birkaç üretici firma için hastadaki gerçek antikor pozitifliğini yansıtan anti-HCV S/CO değerlerini bildirerek HCV tanı algoritmasını genişletmiştir ${ }^{8}$. CDC aynı zamanda anti-HCV S/CO değerlerinin toplum özelliklerine bakılmaksızın sistem verilerinin analizi ile elde edilebileceğini önermiş ve laboratuvarların kendi HCV tanı algoritmalarını oluşturmasına olanak sağlamıştır. Bu amaçla yapılan çalışmalarda anti-HCV test sonuçları, çeşitli doğrulama yöntemleri ile karşılaştırılarak, hastalardaki gerçek viremiyi saptayacak eşik değerler araştırılmıştır. Ülkemizde yapılan çalışmalarda, Altuğlu ve arkadaşları ${ }^{13} 2011$ yılında ikinci nesil anti-HCV testi ile reaktif olan 309 hasta sonucunu "line immunoassay (LIA)" yöntemi ile doğrulamışlardır. Buna göre, \%91.2 duyarlılık ve \%81.4 özgüllük ile anti-HCV test sonucu S/CO değeri 3.27'nin üzerinde olan hastalarda yüksek antikor pozitifliği olduğu ve ek teste gerek olmadığı sonucuna varılmıştır. Şanlıdağ ve arkadaşlarının 
2016 yılında yaptıkları çok merkezli retrospektif bir çalışmada ${ }^{14} 658$ hastanın anti-HCV düzeyleri ile HCV RNA arasındaki korelasyon incelenmiştir. Bu çalışmada eşik değerin en iyi noktasını tespit edebilen yöntem olan ROC analizi kullanılmış; buna göre en uygun S/ CO değeri beş olarak bulunmuş ve duyarlıık \%95.6, özgüllük \%52.7; pozitif ve negatif prediktif değerleri ise sırasıyla \%43.2 ve \%96.9 olarak hesaplanmıştır. Araştırmacılar bu çalışmanın sonucunda düşük titrede anti-HCV reaktifliklerinde, en az iki hafta sonra testin yeni bir örnekle tekrarlanması ve hastanın kliniği ile birlikte değerlendirilmesi, şüphenin devam ettiği durumlarda HCV RNA çalışılması gerektiği düşüncesine varmışlardır.

Karakoç ve arkadaşları tarafından 2017 yılında kan donörleri üzerinde yapılan çok merkezli bir çalışmada ${ }^{15}$ anti-HCV, RIBA ve HCV RNA sonuçları karşılaştırılmıştır. Buna göre, iki farklı ticari kit için farklı eşik değeri hesaplanmıştır. Bu değerler OrthoElA için 8.1, microEIA için 3.4 olarak hesaplanmıştır. Araştırmacılar bu çalışmanın sonunda anti-HCV test sonucu gri zon ve reaktif olan her örneğin iki kuyucukla tekrar çalışılması negatif olanların gerçek negatif olarak kabul edilmesi, tekrar gri zon olan örneklerin takibinin yapılması, reaktif olan örneklerde eşik değerinin altında olan örneklerde RIBA testi çalışılması, cut-off değerine eşit ve üstü olan örneklerde ise nükleik asit testi çalışılması gerektiğini gösteren algoritma oluşturmuşlardır.

Amerika Birleşik Devletleri'nde, 2011 yılında yapılan retrospektif çalışmada, 3082 adet anti-HCV reaktif olan örnekte HCV RNA ve RIBA ile doğrulama testi yapılmıştır. Buna göre; 3, 8 ve 20 olmak üzere üç ayrı anti-HCV S/CO değeri elde edilmiştir. Bu çalışmada elde edilen eşik değer kullanılarak HCV tanı algoritması; anti-HCV S/CO değeri < 3.0 olan hasta örneklerinde gerçek anti-HCV negatifliği, anti-HCV S/CO değeri 3.0-19.9 arasında ek test olarak RIBA yapılması RIBA pozitif bulunan hasta örneklerine HCV RNA çalışılması, anti-HCV S/CO değeri > 20.0 olan hasta örneklerinde vireminin tespiti için ek test yapılmadan HCV RNA çalışılması gerektiği sonucuna varılmıştır ${ }^{16}$.

İtalya'da 2012 yılında yapılan retrospektif çalışmada 313 hastanın anti-HCV S/CO değerleri RIBA sonuçlarıyla karşılaştııılmıştır. Pozitif prediktif değeri \%95 olan 10.3 değeri seçilerek kendi laboratuvarları için HCV tanı algoritmasını; anti-HCV S/CO değeri 10.3'ün altında olan hastalarda ek olarak RIBA testi yapılması, anti-HCV S/CO $\geq 10.3$ olan hastalarda ise bu değerin, hastaların \%95'inde gerçek antikor değerini yansıttığı ve bu nedenle ek teste gerek olmadan doğrudan anti-HCV test sonucunun raporlanması şeklinde düzenlemişlerdir ${ }^{17}$.

Çin'de 2016 yılında yapılan retrospektif bir çalışmada 288 anti-HCV reaktif test sonuçları ile RIBA test sonuçları karşılaştırılmıştır. Bu çalışmada anti-HCV S/CO eşik değerinin 12.27 (\%97.8 duyarlıık ve \%86 özgüllük)'ye yükseltilmesi ile anti-HCV S/CO $\geq 1$ kullanıldığında ortaya çıkan yanlış pozitif sonuçların önüne geçilebileceği sonucuna varılmıştır ${ }^{18}$.

Çalışmamızın sonuçları göz önüne alındığında anti-HCV test sonucu S/CO < 7.13 saptanması durumunda HCV RNA testi çalışılmaması, hastada HCV yönünden klinik şüphenin devam etmesi durumunda en az iki hafta sonra anti-HCV testinin yeni bir örnekle tekrarlanması, yeniden reaktiflik saptandığında HCV RNA çalışılması önerilebilir. Yeni antiHCV eşik değerimizin pozitif prediktif değerinin düşük olması nedeniyle eşik değerinin 
üzerinde saptanan anti-HCV reaktifliklerinde hastada viremi olmaması ihtimali de göz önünde bulundurulmalıdır. Bu bilgiler ışığında, 7.13 S/CO'nun üzerindeki tüm reaktifliklerde HCV RNA çalışılması şeklinde tanı algoritmamız düzenlenmiştir (Şekil 2).

Sonuç olarak, yüksek duyarlılığı, düşük maliyeti, çok fazla teknik beceri gerektirmemesi, otomatize cihazlarla çalışılabilme olasılığı ve test sonuçlanma süresinin kısa olması gibi nedenlerle birçok laboratuvarda kullanımda olan anti-HCV antikor testleri, HCV tanı ve taramasında vazgeçilmez bir yöntemdir. Ancak, ülkemiz gibi HCV prevalansının düşük

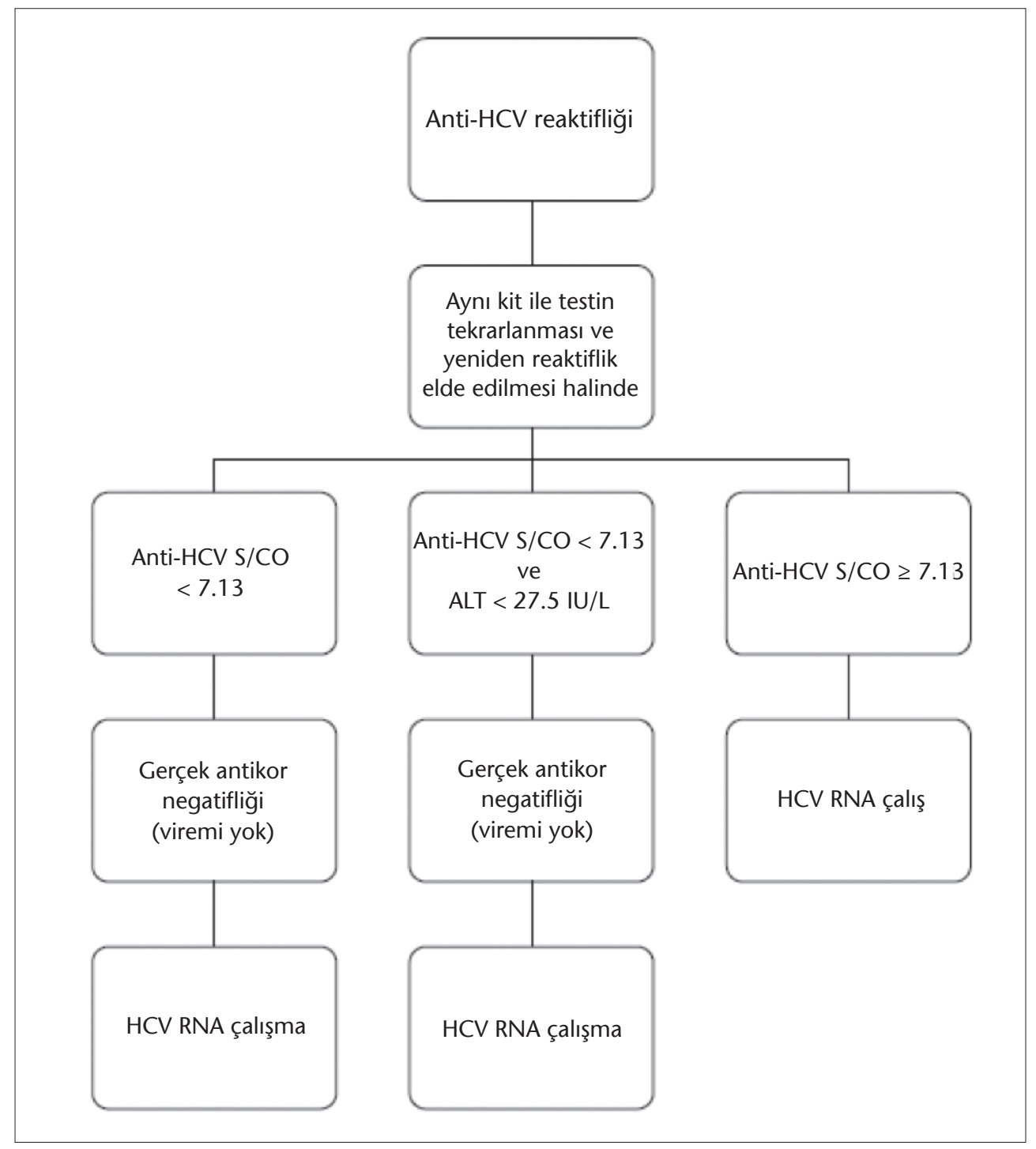

Şekil 2. Çalışmamızın sonunda laboratuvarımız için oluşturduğumuz HCV tanı algoritması. 
olduğu toplumlarda yalancı pozitif test sonuçları sıktır. Yeni eşik değerinin laboratuvar iş akışı içerisinde kullanılmasıyla birlikte yalancı pozitif anti-HCV test sonuçları ve buna bağlı olarak çalışılan HCV RNA test sayılarının azaltılabileceği düşüncesindeyiz.

\section{ÇIKAR ÇATIŞMASI}

Yazarlar bu makale ile ilgili herhangi bir çıkar çatışması bildirmemişlerdir.

\section{KAYNAKLAR}

1. Choo QL, Kuo G, Weiner AJ, Overby LR, Bradley LW, Houghton M . Isolation of a cDNA clone derived from a bloodborne non-A, non-B viral hepatitis genome. Science 1989;244(4902):359-62.

2. Öktem MA. Hepatit C, pp: 159-164. In: Altındiş M, Tabak F (eds). Hepatit Mikrobiyolojisi. 2015, 1. Baskı. İstanbul Tıp Kitabevi, İstanbul.

3. Ray SC, Thomas DL. Hepatitis C, pp: 1904-1927. In: Bennett JE, Dolin R, Blaser MJ (eds). Mandell, Douglas and Bennett's Principles and Practice of Infectious Diseases. 2015, $8^{\text {th }}$ ed. Churchill Livingstone, Philadelphia.

4. World Health Organization. Hepatitis C. Available at: http://www.who.int/mediacentre/factsheets/ fs164/ en/ (erişim tarihi: 12.12.2017).

5. Türkiye Viral Hepatit Önleme ve Kontrol Programı 2018-2023, Sağlık Bakanlığı Yayın No: 1102, 2018, Ankara.

6. Tabak F. Virus enfeksiyonları, pp: 1694-1698. In: Willke Topçu A, Söyletir G, Doğanay M (eds). Enfeksiyon Hastalıkları ve Mikrobiyolojisi. 2017, 4. Baskı. Nobel Tıp Kitabevleri, İstanbul.

7. Us AD. Viral enfeksiyonların serolojik tanısı, pp: 241-245. In: Us AD (ed). Temel İmmünoloji ve Seroloji. 2016, 2. Baskı. Hipokrat Kitabevi, Ankara.

8. Centers for Disease Control and Prevention. Hepatitis C. Available at: https://www.cdc.gov/hepatitis/hcv/ labtesting.htm (erişim tarihi: 12.12.2017).

9. Couroucé AM, Le Marrec N, Girault A, Ducamp S, Simon N. 1994. Anti-hepatitis C virus (anti-HCV) seroconversion in patients undergoing hemodialysis: comparison of second and third generation anti-HCV assays. Transfusion 1994;34(9):790-5.

10. Selvarajah S, Busch MP. Transfusion transmission of HCV, a long but successful road map to safety. Antivir Ther 2012;17(7 Pt B):1423-9.

11. Gretch DR. Diagnostic tests for hepatitis C. Hepatology 1997;26(3 S):43S-7S.

12. Alter MJ, Kuhnert WL, Finelli L. Guidelines for laboratory testing and result reporting of antibody to hepatitis $C$ virus. Centers for Disease Control and Prevention. MMWR 2003;52(RR03):1-16.

13. Altuğlu i, Gürsel D, Aksoy A, Orman M, Erensoy S. The importance and role of anti-HCV signal/cutoff ratio in diagnosis of hepatitis C virus infection. Ege Tıp Dergisi / Ege Journal of Medicine 2011;50(4):223-8.

14. Şanlıdağ T, Akçalı S, Ecemiş T, Süer K, Erbay Dündar P, Arıkan A, et al. Hepatit C virus (HCV) enfeksiyonunun tanısında anti-HCV düzeyi (S/Co) ile HCV-RNA arasındaki korelasyonun araştırılması. Mikrobiyol Bul 2016;50(3):508-10.

15. Karakoç AE, Berkem R, Irmak H, Demiröz AP, Yenicesu I, Ertuğrul N, et al. Investigation of an algorithm for anti HCV EIA reactivity in blood donor screening in Turkey in the absence of nucleic acid amplification screening. Transfus Apher Sci 2017;56(5):732-7.

16. Lai KKY, Jin M, Yuan S, Larson MF, Dominitz JA, Bankson DD. Improved reflexive testing algorithm for hepatitis C infection using signal-to-cut off ratios of a hepatitis C virus antibody assay. Clin Chem 2011;57(7):1050-6.

17. Moretti M, Pieretti B, Masucci A, Sisti D, Rocchi M, Delprete E. Role of signal-to-cut off ratios in hepatitis C virus antibody detection. Clin Vaccine Immunol 2012;19(8):1329-31.

18. Pan J, Li X, He G, Feng P, Zhang X, Qui Y. Reflex threshold of signal-to-cut-off ratios of the Elecsys anti-HCV II assay for hepatitis C virus infection. J Infect Dev Ctries 2016;10(9):1031-4. 